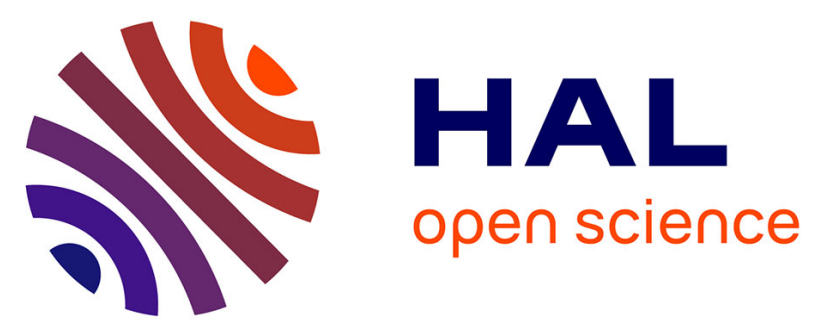

\title{
High-Throughput Screening and Hit Validation of Extracellular-Related Kinase 5 (ERK5) Inhibitors
}

Stephanie M. Myers, Ruth H. Bawn, Louise C. Bisset, Timothy J. Blackburn, Betty Cottyn, Lauren Molyneux, Ai-Ching Wong, Celine Cano, William Clegg, Ross. W. Harrington, et al.

\section{To cite this version:}

Stephanie M. Myers, Ruth H. Bawn, Louise C. Bisset, Timothy J. Blackburn, Betty Cottyn, et al.. High-Throughput Screening and Hit Validation of Extracellular-Related Kinase 5 (ERK5) Inhibitors. ACS Combinatorial Science, 2016, 18, pp.444-455. 10.1021/acscombsci.5b00155 . hal-02634305

\section{HAL Id: hal-02634305 https://hal.inrae.fr/hal-02634305}

Submitted on 27 May 2020

HAL is a multi-disciplinary open access archive for the deposit and dissemination of scientific research documents, whether they are published or not. The documents may come from teaching and research institutions in France or abroad, or from public or private research centers.
L'archive ouverte pluridisciplinaire HAL, est destinée au dépôt et à la diffusion de documents scientifiques de niveau recherche, publiés ou non, émanant des établissements d'enseignement et de recherche français ou étrangers, des laboratoires publics ou privés. 


\title{
High-Throughput Screening and Hit Validation of Extracellular- Related Kinase 5 (ERK5) Inhibitors
}

\author{
Stephanie M. Myers, ${ }^{\dagger}$ Ruth H. Bawn, ${ }^{\dagger}$ Louise C. Bisset, ${ }^{\S}$ Timothy J. Blackburn, ${ }^{\dagger}$ Betty Cottyn, ${ }^{\dagger}$
} Lauren Molyneux, ${ }^{\dagger}$ Ai-Ching Wong, ${ }^{\|}$Celine Cano, ${ }^{\dagger}$ William Clegg, ${ }^{\dagger}$ Ross. W. Harrington, ${ }^{\dagger}$ Hing Leung, ${ }^{\perp}$ Laurent Rigoreau, $\|$ Sandrine Vidot, ${ }^{\dagger}$ Bernard T. Golding, ${ }^{\dagger}$ Roger J. Griffin, ${ }^{\dagger}$ Tim Hammonds, ${ }^{\Uparrow}$ David R. Newell, ${ }^{\S}$ and Ian R. Hardcastle*,

${ }^{\dagger}$ Newcastle Cancer Centre, Northern Institute for Cancer Research and School of Chemistry, Bedson Building, Newcastle University, Newcastle upon Tyne, NE1 7RU, U.K.

${ }^{\ddagger}$ School of Chemistry, Newcastle University, Bedson Building, Newcastle upon Tyne, NE1 7RU, U.K.

${ }^{\S}$ Newcastle Cancer Centre, Northern Institute for Cancer Research, Medical School, Framlington Place, Newcastle University, Paul O'Gorman Building, Newcastle upon Tyne, NE2 4HH, U.K.

"Cancer Research Technology, Ltd., Discovery Laboratories, Wolfson Institute for Biomedical Research, The Cruciform Building, Gower Street, London, WC1E 6BT, U.K.

${ }^{\perp}$ The Beatson Institute for Cancer Research, Garscube Estate, Switchback Road, Bearsden, Glasgow G61 1BD, U.K.

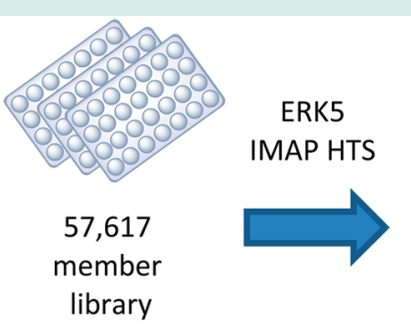

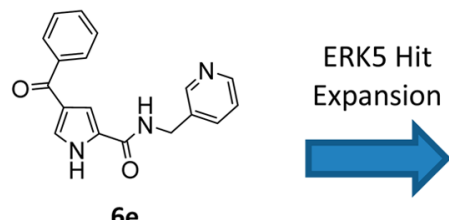

$6 \mathrm{e}$

ERK5 HTS IC $50=8.0$ uM

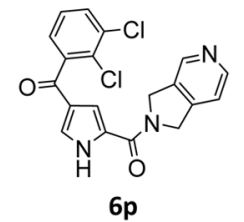

ERK5 IC $\mathrm{IS}_{50}=2.7 \mathrm{uM}$

p38 alpha $=>120$ uM

ABSTRACT: The extracellular-related kinase 5 (ERK5) is a promising target for cancer therapy. A high-throughput screen was developed for ERK5, based on the IMAP FP progressive binding system, and used to identify hits from a library of 57617 compounds. Four distinct chemical series were evident within the screening hits. Resynthesis and reassay of the hits demonstrated that one series did not return active compounds, whereas three series returned active hits. Structure-activity studies demonstrated that the 4-benzoylpyrrole-2-carboxamide pharmacophore had excellent potential for further development. The minimum kinase binding pharmacophore was identified, and key examples demonstrated good selectivity for ERK5 over p38 $\alpha$ kinase.

KEYWORDS: extracellular-related kinase 5 (ERK5), cancer therapy, high-throughput screening, structure-activity studies, library, p38 $\alpha$ kinase

\section{INTRODUCTION}

The extracellular-related kinase 5 (ERK5), also known as big map kinase (BMK1), is a 816 amino acid protein kinase that forms part of a noncanonical MAP kinase pathway in cells. ${ }^{1}$ Extracellular stimulation, in the form of growth factors, such as epidermal growth factor (EGF), nerve growth factor (NGF), vascular endothelium growth factor (VEGF), and fibroblast growth factor-2 (FGF-2), initiates a signaling cascade from the cell surface to nuclear transcription factors via ERK5. ${ }^{2}$ Unlike the linear canonical Ras/Raf/MEK/ERK pathway, the ERK5 signaling cascade occurs independently of Raf. ${ }^{3}$ ERK5 is activated specifically by MEK5, which is in turn activated by $\operatorname{MEKK} 2 / 3$. $^{1 \mathrm{a}, 4}$
ERK5 is structurally different from the other members of the ERK subfamilies. A unique loop-12 structure and extended Cterminal domain ( $\sim 00$ amino acids) gives ERK5 its characteristic structure. ${ }^{2,4}$ The C-terminal extension harbors nuclear localization and export sequences, two proline-rich domains, a transcriptional activating domain, and MEF2 interacting region. The large C-terminal unique to ERK5 is autophosphorylated at multiple sites, resulting in an increase in transcriptional activity. ${ }^{5}$

Phosphorylation of ERK5 results in activation of a number of transcription factors including MEF2, c-Myc, c-Jun, c-Fos, Fra-1,

Received: October 14, 2015

Revised: June 13, 2016

Published: July 11, 2016 
and NF $\kappa B^{6}{ }^{6}$ ERK5 also phosphorylates and activates p90 RSK, also involved in signal transduction. ${ }^{7}$ An increasing body of mechanistic data indicates that ERK5 plays a key role in tumor biology, that is, cell proliferation and survival, invasion and metastasis, and angiogenesis. ${ }^{8}$

Expression of ERK5 is significantly up-regulated in advanced prostate cancer and has been identified as an independent prognostic biomarker for aggressive disease. ${ }^{9}$ ERK5 is overexpressed in $20 \%$ of breast cancer patients and its expression is an independent prognostic biomarker for reduced disease-free survival. ${ }^{10}$ In hepatocellular carcinoma (HCC), ERK5 overexpression has been reported, associated with gene amplification at the $17 \mathrm{p} 11$ chromosome fragment, harboring the MAPK7 gene. ${ }^{11}$ High levels of ERK5 were found to correlate with more aggressive and metastatic stages in fresh samples from human clear cell renal cell carcinoma. ${ }^{12}$

To date, three small-molecule inhibitors of the MEK5/ERK5 pathway have been described. The indolinone-based inhibitors, BIX02188 (1a) and BIX02189 (1b), are dual inhibitors of the MEK5/ERK5 cascade. Both compounds inhibit MEK5 with nanomolar potency, whereas modest activity was reported for ERK5. ${ }^{13}$ Benzo[e]pyrimido- $[5,4-b]$ diazepine- $6(11 H)$-one (XMD8-92, 2) is a potent ERK5 inhibitor which exhibits antiproliferative and antiangiogenic effects on HeLa cells in mouse xenograft models. ${ }^{14}$ An X-ray crystal structure of 2 bound to ERK5 shows the inhibitor bound to the Met140 in the kinase hinge via a pair of hydrogen bonds from the aniline and pyrimidine nitrogens, and an additional water-bridged hydrogen bond from the diazepinone carbonyl to Asp200 and Glu102 in the DFG loop. ${ }^{15}$ However, some of the in vivo activity of $\mathbf{2}$ has been attributed to off-target activities, for example, inhibition of doublecortin-like kinase 1 (DCLK-1) in pancreatic cancer. ${ }^{16}$ Inhibition of ERK5 or siRNA knockdown has been shown to inhibit the growth of HCC cell lines, in vitro and in vivo. ${ }^{17}$ ERK5 signaling has been shown to be essential for chemically induced carcinogenesis in skin by erk5 gene deletion or ERK5 inhibition (with 2). ${ }^{18}$ The combination of doxorubicin and either erk5 gene deletion or ERK5 inhibition (with 2) was found to be additive in inflammation-driven tumor models. Thus, pharmacological inhibition of ERK5 may provide an opportunity for the treatment of inflammation-driven, invasive or metastatic cancers where ERK5 is deregulated. Given the strong link between ERK5 mediated signaling and malignancy, there remains a strong need to develop selective tool molecules to fully elucidate the effect of ERK5 inhibition in vivo. For this reason, we sought to discover novel ERK5 inhibitory chemotypes through high-throughput screening as chemical tools and for development as therapeutic agents.

In this Research Article, we describe the development of a high-throughput screening assay for ERK5 inhibition based on the IMAP FP format that was used to identify four discrete series of hit molecules. Validation of each series was attempted by resynthesis and retesting of selected members from each series. Preliminary structure activity studies were obtained resulting in the identification of one series for further optimization.

\section{DEVELOPMENT AND EXECUTION OF ERK5 IMAP SCREEN}

Assay Development. The discovery of kinase inhibitors using high-thoughput screening is well established. ${ }^{19}$ In our case, expression of active ERK5 protein required coexpression of MEK5. The screen was developed using the IMAP format (Molecular Devices) that relies on the high specificity interaction<smiles>[R]N([R])C(=O)c1ccc2c(c1)NC(=O)/C2=C(/Nc1cccc(CN(C)C)c1)c1ccccc1</smiles><smiles>Cc1ccccc1C(=O)c1c[nH]c(C(=O)NCc2ccco2)c1</smiles>

Table 1

\begin{tabular}{cl} 
number & \multicolumn{1}{c}{ sequence } \\
166 & 5-FAM-AGRSPVD \\
168 & 5-FAM-EAGRSPVDS \\
170 & 5-FAM-HEAGRSPVDSL \\
172 & 5-FAM-RHEAGRSPVDSLS \\
174 & 5-FAM-TRHEAGRSPVDSLSS
\end{tabular}

Table 2

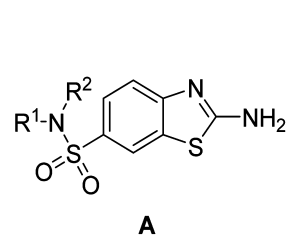<smiles>[R]N([R])S(=O)(=O)c1ccc2sc(N)nc2c1</smiles><smiles>[R]N([R])S(=O)(=O)c1cc(N)ccc1SC#N</smiles>

\begin{tabular}{|c|c|c|c|c|c|c|}
\hline \multirow[b]{2}{*}{ compound } & \multirow[b]{2}{*}{ structure } & \multirow{2}{*}{\multicolumn{2}{|c|}{$\mathrm{R}^{1}$}} & \multirow[b]{2}{*}{$\mathrm{R}^{2}$} & \multicolumn{2}{|c|}{ ERK5 IC $_{50}(\mu \mathrm{M})$} \\
\hline & & & & & HTS & resynthesized $^{a}$ \\
\hline $3 a$ & A & & $-\left(\mathrm{CH}_{2}\right)_{4}-$ & & 0.057 & $51 \pm 5.0$ \\
\hline $3 b$ & A & Et & & $\mathrm{Me}$ & 0.087 & $85 \pm 5.0$ \\
\hline $3 c$ & A & $\mathrm{Me}$ & & $\mathrm{H}$ & 0.087 & \\
\hline $3 d$ & A & Et & & $\mathrm{H}$ & 0.11 & \\
\hline $3 e$ & A & $\mathrm{CH}$ & $=\mathrm{CHCH}_{2}-$ & $\mathrm{H}$ & 0.13 & \\
\hline $3 f$ & A & $s-\mathrm{B}$ & & $\mathrm{H}$ & 0.13 & \\
\hline $3 g$ & A & & $-\left(\mathrm{CH}_{2}\right)_{5}-$ & & 0.46 & \\
\hline $3 \mathrm{~h}$ & A & $i-\mathrm{Pr}$ & & $\mathrm{H}$ & 0.60 & \\
\hline $3 \mathbf{i}$ & A & $n$-P & & $\mathrm{H}$ & 0.89 & $>120^{b}$ \\
\hline $3 \mathbf{j}$ & A & Et & & $\mathrm{Et}$ & 0.93 & \\
\hline $3 \mathrm{k}$ & A & & $\left.\mathrm{CH}_{2}\right)_{2} \mathrm{O}\left(\mathrm{CH}_{2}\right)_{2}$ & & 5.13 & \\
\hline $9 a$ & B & & $-\left(\mathrm{CH}_{2}\right)_{4}-$ & & & $29 \pm 1.3$ \\
\hline $9 b$ & B & Et & & $\mathrm{Me}$ & & $21 \pm 1.5$ \\
\hline $12 a$ & $\mathrm{C}$ & & $-\left(\mathrm{CH}_{2}\right)_{4}-$ & & & $2.3 \pm 1.5$ \\
\hline $12 b$ & $\mathrm{C}$ & Et & & $\mathrm{Me}$ & & $>120^{b}$ \\
\hline
\end{tabular}

${ }^{a}$ Values are the mean of at least 3 determinations \pm SD. ${ }^{b} n=2$.

of phospho groups on a fluorescently tagged peptide with $\mathrm{M}^{3+}$ containing nanoparticles. The IMAP format was chosen as a robust and efficient method of determining kinase activity using a "mix-and-measure" format with a nonradioactive, fluorescence output.

Preliminary experiments to determine a suitable peptide substrate for the IMAP FP assay used a commercial source of the enzyme and were based on sequence of the natural substrate of ERK5, and were augmented with a substrate finder kit. Five 
Table 3. ERK5 Inhibitory Activity of Nicotinonitrile Series $4 a-k$

\begin{tabular}{|c|c|c|c|c|}
\hline \multirow[b]{2}{*}{ compd } & \multirow[b]{2}{*}{$\mathrm{R}^{1}$} & \multirow[b]{2}{*}{$\mathrm{R}^{2}$} & \multicolumn{2}{|c|}{ ERK5 IC $_{50}(\mu \mathrm{M})$} \\
\hline & & & HTS & Resynthesized $^{a}$ \\
\hline $4 a$ & 4-F-Ph & $\mathrm{Ph}$ & 1.6 & $4.9 \pm 0.3$ \\
\hline $4 b$ & 3-F-Ph & $\mathrm{Ph}$ & & $>120^{b}$ \\
\hline $4 c$ & 2-F-Ph & $\mathrm{Ph}$ & & $34.3 \pm 6.4$ \\
\hline $4 d$ & $\mathrm{Ph}$ & $\mathrm{Ph}$ & & $>120^{b}$ \\
\hline $4 e$ & 4- $\left(\mathrm{CF}_{3}\right)-\mathrm{Ph}$ & $\mathrm{Ph}$ & & $>120^{b}$ \\
\hline $4 f$ & 2,4-di-F-Ph & $\mathrm{Ph}$ & & $72.9 \pm 26.1$ \\
\hline $4 g$ & 4-Py & $\mathrm{Ph}$ & & $65.1 \pm 12.4$ \\
\hline $4 h$ & $4-\mathrm{MeOPh}$ & $\mathrm{Ph}$ & & $>120^{b}$ \\
\hline $4 \mathrm{i}$ & $\mathrm{Ph}$ & 4-MeOPh & & $>120^{b}$ \\
\hline $4 j$ & $\mathrm{Ph}$ & $\mathrm{CH}_{3}$ & & $>120^{b}$ \\
\hline $4 k$ & $\mathrm{CH}_{3}$ & $\mathrm{CH}_{3}$ & & $>120^{b}$ \\
\hline
\end{tabular}

${ }^{a}$ Values are the mean of at least 3 determinations \pm SD. ${ }^{b} n=2$.

peptide sequences were designed based around the reported site of phosphorylation of MEF2C by ERK5, with the expected serine phosphorylation site highlighted in red (Table 1). ${ }^{1}$ The peptides were tested using the IMAP FP Progressive Binding System (Molecular Devices) in the absence and presence of ERK5 (Carna Biosciences).

The IMAP FP substrate finder kit for serine/threonine kinases plate 2 (molecular devices) covering CMGC, CK1, STE, and TKL portions of the kinome was used to identify potential peptide substrates phosphorylated by ERK5. The FAM-EGFRderived peptide (LVEPLTPSGEAPNQK-5FAM-COOH) proved optimal.

Kinetic studies determined the ERK5 $K_{\mathrm{M}}^{\mathrm{app}}$ to be $300 \mu \mathrm{M}$. Ideally, kinase screens are run with the ATP concentration equal to the $K_{\mathrm{M}}$, however, in this case the IMAP format did not return acceptable results at a high ATP concentration $(300 \mu \mathrm{M})$, presumably due to interference of ATP with the interaction of the phospho peptide with the metal nanoparticles. For this reason, the HTS assay was run at the maximum acceptable ATP concentration $(100 \mu \mathrm{M})$ to allow "mix-and-measure" determinations.

High-Throughput Screening for ERK5 Inhibitors. To identify inhibitors of ERK5 the IMAP HTS assay was set up and a library of 57617 small molecules was screened (final DMSO concentration of $4 \%$ and a total reaction volume of $40 \mu \mathrm{L}$ ). The library was composed of a 48479 member diverse library and a 9136 member kinase focused library, both libraries were sourced from commercial vendors. $Z^{\prime}$ factors for each plate were calculated using eq 2 , and were typically $0.6-0.8$. Plates with $Z^{\prime}$ factors below 0.4 were rescreened (Supporting Information).

$$
\begin{aligned}
& \frac{v}{[E]}=\frac{k_{\mathrm{cat}}[S]}{\left(K_{\mathrm{m}}+[S]\right)} \\
& Z^{\prime}=1-\frac{3 \sigma_{c+}+3 \sigma_{c-}}{\left|\mu_{c+}-\mu_{c-}\right|}
\end{aligned}
$$

where $\sigma$ and $\mu$ represent the standard deviation and mean of the positive $(\mathrm{c}+)$ and negative $(\mathrm{c}-)$ plate controls, respectively.

HTS Results. The HTS assay returned 245 active compounds ( $0.5 \%$ hit rate), that is, $>50 \%$ inh at $30 \mu \mathrm{M}$, from the 57617 member library. Active compounds (245) showing $>50 \%$ inhibition in the screen were resupplied from stock or commercial vendors and retested at 30,10 , and $3.3 \mu \mathrm{M} .71$ active compounds, giving $>30 \%$ mean inhibition, were treated as confirmed hits $(0.10 \%$ overall hit-rate $)$ and assayed over a full $\mathrm{IC}_{50}$ range. $\mathrm{IC}_{50}$ determinations required a two stage process whereby the reaction occurred initially in the absence of the IMAP reagent, followed by subsequent addition of the IMAP reagent, to allow the $K_{M}$ concentration of ATP to be used.

The hit compounds produced inhibition curves with $\mathrm{IC}_{50}$ values ranging from 0.6 to $76 \mu \mathrm{M}$ (1 compound $>120 \mu \mathrm{M})$. Confirmed hits were clustered according to common structures, revealing four promising chemical series. SAR around the hits was expanded by assaying related in-house compounds and close analogues from commercial suppliers. From these results, four compound series were selected for validation by resynthesis prior to progressing to hit-to-lead studies: 2 -amino- $N, N$-alkylbenzo[d] thiazole-6-sulfonamides (Table 2, 3a-c), 4-substituted-2(substitutedthio)-6-phenylnicotinonitriles (Table 3, 4a,b), 4amino-2-(arylamino)pyrimidine-5-carbonitriles (Table 5, 5ac), and 4-aroyl-N-alkyl-1H-pyrrole-2-carboxamides (Table 6, $6 a-e)$.

\section{SYNTHESIS}

Benzothiazole Series 3. Numerous methods have been described for the synthesis of benzothiazoles. ${ }^{20}$ For the synthesis of compounds $3 \mathbf{a}$ and $\mathbf{b}$ and analogues, we used the reported reaction of anilines with potassium thiocyanate-copper(II) sulfate (Scheme 1). ${ }^{21}$ The required 4-aminophenylsulfonamides $(7 \mathbf{a}-\mathbf{c})$ were prepared by reduction of the corresponding nitro compounds $(\mathbf{8} \mathbf{a}-\mathbf{c})$. The nitro precursors were obtained by coupling the relevant amine with 4-nitrobenzenesulfonyl chloride. The 5-sulfonamide isomer 9a, was prepared via the same method (Scheme 2). Thus, 3-nitrobenzenesulfonyl chloride was reacted with pyrrolidine or $N$-methylethylamine, and the resulting sulfonamides $10 \mathbf{a}$ and $\mathbf{b}$ were reduced to the respective anilines $11 \mathbf{a}$ and $\mathbf{b}$ (Scheme 2). Reactions of $\mathbf{1 1} \mathbf{a}$ and $\mathbf{b}$ with with potassium thiocyanate-copper(II) sulfate gave in each

Scheme $1^{a}$<smiles>O=[N+]([O-])c1ccc(S(=O)(=O)Cl)cc1</smiles><smiles>[R]N([R2])S(=O)(=O)c1ccccc1</smiles>

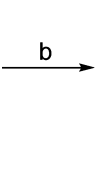

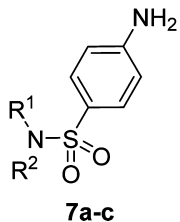

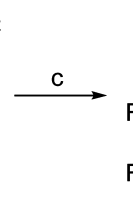

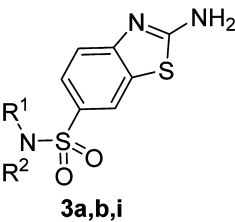

${ }^{a}$ Reagents and conditions: (a) pyrrolidine or $\mathrm{N}$-methylethylamine or propylamine, $\mathrm{Et}_{3} \mathrm{~N}, \mathrm{DCM}$; (b) $\mathrm{Pd} / \mathrm{C}, \mathrm{H}_{2}, \mathrm{EtOAc}$; (c) $\mathrm{KSCN}, \mathrm{Cu}(\mathrm{II}) \mathrm{SO}_{4}$, $\mathrm{MeOH}$. 
Scheme $2^{a}$<smiles>[R]N([R])S(=O)(=O)c1ccc(N)cc1S(=O)(=O)N([R])[R]</smiles>

${ }^{a}$ Reagents and conditions: (a) pyrrolidine or $\mathrm{N}$-methylethylamine, $\mathrm{Et}_{3} \mathrm{~N}, \mathrm{DCM}$; (b) Pd/C, $\mathrm{H}_{2}, \mathrm{EtOAc}$; (c) $\mathrm{KSCN}, \mathrm{Cu}(\mathrm{II}) \mathrm{SO}_{4}, \mathrm{MeOH}$.

Scheme $3^{a}$<smiles>[R]C=CC(=O)C=C[R]CCC</smiles><smiles>[R]OC(=O)CNC(=O)CSc1nc([R])cc([R])c1C#N</smiles>

15a: $X=O, R=t-B u$

15b: $X=O, R=E t$<smiles>[R]NC(=O)CNC(=O)CSc1nc([R])cc([R])c1C#N</smiles>

$$
\begin{aligned}
& \text { 16: } \mathrm{R}=\mathrm{PMB} \square \mathrm{f} \\
& \text { 17: } \mathrm{R}=\mathrm{H}
\end{aligned}
$$

${ }^{a}$ Reagents and conditions: (a) KOH, EtOH, RT; (b) method A, $\mathrm{S}_{8}$, morpholine, EtOH, $80^{\circ} \mathrm{C} 30$ min then malononitrile; or method $\mathrm{B}, 2$ cyanothioacetamide, $1.6 \mathrm{M} \mathrm{NaOMe}$ in $\mathrm{MeOH}, 80^{\circ} \mathrm{C}$; (c) tert-butyl or ethyl 2-(2-bromoacetamido)acetate, $\mathrm{K}_{2} \mathrm{CO}_{3}$ or $\mathrm{KOH}, \mathrm{DMF}, 100{ }^{\circ} \mathrm{C}$; (d) TFA, RT; (e) p-methoxybenzylamine, HBTU, DIPEA, DMF, 60 ${ }^{\circ} \mathrm{C}$; (f) TFA, $70{ }^{\circ} \mathrm{C}$. NB: No base was required in step $\mathrm{c}$ after step $\mathrm{b}$ (method B), as an excess of NaOMe was used in step b

case, besides the desired 5-substituted benzothiazole $9 \mathbf{a}$ and $\mathbf{b}$, a significant quantity of a thiocyanatobenzene (12a and $\mathbf{b})$.

Nicotinonitrile Series 4. The first synthetic approach considered for the synthesis of 3-cyanopyridines was based on

\section{Scheme $5^{a}$}<smiles>[X]C(=O)CSc1nc(-c2ccccc2)cc(-c2ccc(F)cc2)c1C#N</smiles>

20: $\mathrm{X}=\mathrm{OCH}_{3}$ 21: $\mathrm{X}=\mathrm{NH}_{2}$

${ }^{a}$ Reagents and conditions: (a) methyl bromoacetate, $\mathrm{KOH}, \mathrm{DMF}$, reflux, or chloroacetamide, $\mathrm{NaOAc} \cdot 3 \mathrm{H}_{2} \mathrm{O}$, ethanol, reflux.

\section{Scheme $6^{a}$}

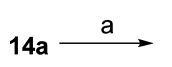<smiles>[R]OC(=O)CCSc1nc(-c2ccccc2)cc(-c2ccc(F)cc2)c1C#N</smiles>

22a: $\mathrm{n}=3, \mathrm{R}=t$-Bu

22b: $\mathrm{n}=4, \mathrm{R}=t-\mathrm{Bu}$

23a: $n=3, R=H$

23b: $n=4, R=H$

${ }^{a}$ Reagents and conditions: (a) $\mathrm{RBr}, \mathrm{K}_{2} \mathrm{CO}_{3}$, THF, $100{ }^{\circ} \mathrm{C}$; (b) TFA, RT.

the route reported by Shestopalov et al. ${ }^{22}$ For example, 4fluorochalcone 13a, prepared via Claisen-Schmidt condensation of acetophenone with 4-fluorobenzaldehyde, was treated

Scheme $4^{a}$<smiles>COC(=O)C1CCCN1C(=O)CSc1nc(-c2ccccc2)cc(-c2ccc(F)cc2)c1C#N</smiles>

${ }^{a}$ Reagents and conditions: (a) bromoacetyl chloride, $\mathrm{CaCO}_{3}, \mathrm{CHCl}_{3}, \mathrm{H}_{2} \mathrm{O}, 0^{\circ} \mathrm{C}$; (b) 14a, $\mathrm{KOH}, \mathrm{DMF}$, reflux. 
Scheme $7^{a}$

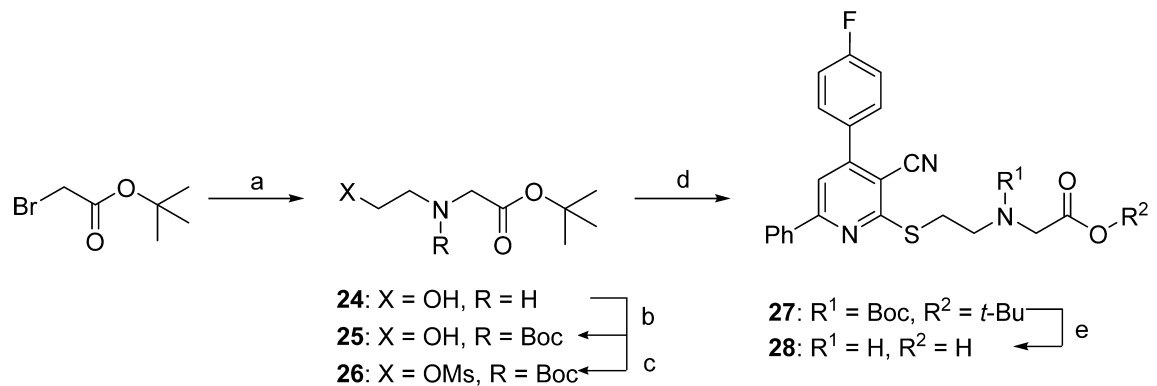

${ }^{a}$ Reagents and conditions: (a) ethanolamine, RT; (b) $\mathrm{Boc}_{2} \mathrm{O}, \mathrm{Et}_{3} \mathrm{~N}, \mathrm{DCM}, 0{ }^{\circ} \mathrm{C}-\mathrm{RT}$; (c) $\mathrm{MsCl}, \mathrm{Et}_{3} \mathrm{~N}, \mathrm{DCM}, 0{ }^{\circ} \mathrm{C}-\mathrm{RT}$; (d) 14a, DMF, $100{ }^{\circ} \mathrm{C}$; (e) TFA, RT.

Scheme $8^{a}$

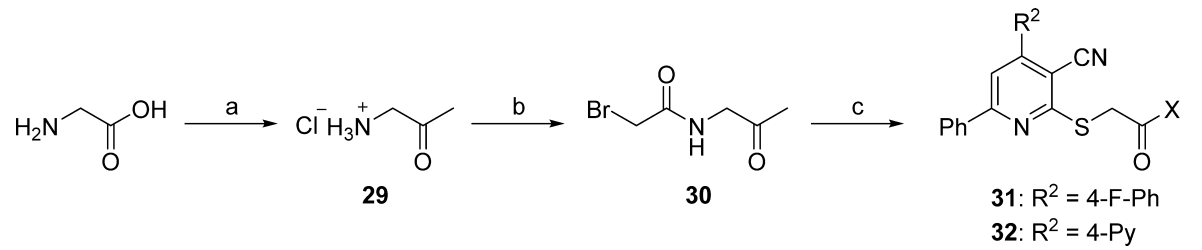

${ }^{a}$ Reagents and conditions: (a) (i) $\mathrm{Ac}_{2} \mathrm{O}$, pyridine, reflux; (ii) $\mathrm{HCl}, \mathrm{H}_{2} \mathrm{O}$, reflux; (b) bromoacetyl chloride, $\mathrm{CaCO}_{3}, \mathrm{DCM}$, reflux; (c) 14a or 14g, $\mathrm{K}_{2} \mathrm{CO}_{3}$, DMF, $100{ }^{\circ} \mathrm{C}$.

\section{Scheme $9^{a}$}

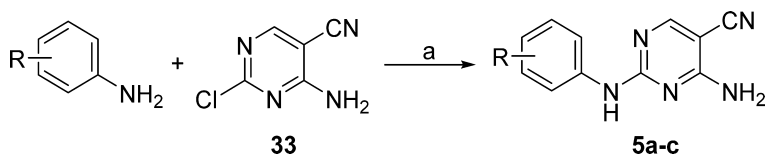

${ }^{a}$ Reagents and conditions: (a) DMF, $100{ }^{\circ} \mathrm{C}$.

Scheme $10^{a}$

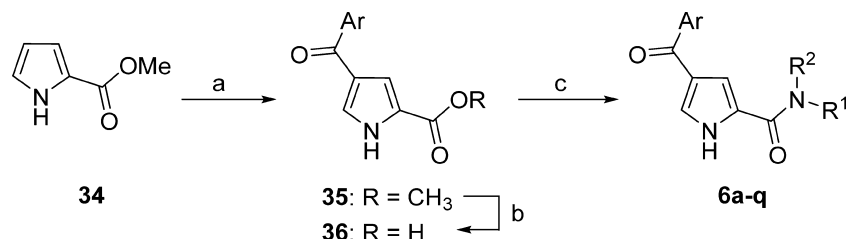

${ }^{a}$ Reagents and Conditions: (a) $\mathrm{ArCOCl}, \mathrm{AlCl}_{3}, \mathrm{DCM}, 0{ }^{\circ} \mathrm{C}-\mathrm{RT}$; (b) $\mathrm{LiOH}, \mathrm{THF}, \mathrm{H}_{2} \mathrm{O}, 60^{\circ} \mathrm{C}$; (c) (i) CDI, THF, $70{ }^{\circ} \mathrm{C}$; (ii) $\mathrm{R}^{1} \mathrm{R}^{2} \mathrm{NH}, 50$ ${ }^{\circ} \mathrm{C}-\mathrm{RT}$.

with elemental sulfur and morpholine in ethanol at reflux, followed by malononitrile, to give pyridinethione $14 \mathrm{a}$ in moderate yield (Method A, Scheme 3). Isolation of the intermediate pyridinethiones 14 required extensive purification, attributed to the propensity of this intermediate to tautomerise, and its readiness to oxidize under atmospheric conditions.

Consideration of the likely mechanism of the one-pot sequence of the cyclization reaction prompted the replacement of the sulfur and malononitrile with 2-cyanothioacetamide for the Michael addition in an alternative route (Method B, Scheme 3). Reactions were performed under nitrogen to avoid oxidative side-reactions. The crude intermediate 14 was used directly in the alkylation step, to avoid a lengthy purification, giving cyanopyridines $15 \mathbf{a}-\mathbf{k}$. Method B allowed isolation of 15a in an improved 54\% yield over 2 steps. Deprotection with TFA gave acids $\mathbf{4 a - k}$ in near quantitative yield (99\%). The carboxamide 17 was prepared from $4 \mathbf{a}$ by a HBTU-mediated coupling with $p$ methoxybenzylamine giving amide 16 , which was deprotected with TFA.

Further variations to the thioether group were introduced via alkylation of 14a (Schemes 4-7). The acetamide derivatives 31 and 32 were prepared by the alkylation of $14 \mathrm{a}$ and $14 \mathrm{~g}$, respectively, with bromoacetamide 30 , which was obtained by reaction of aminoacetone hydrochloride 29 with bromoacetyl chloride (Scheme 8). ${ }^{23}$

\section{Scheme $11^{a}$}<smiles>COC(=O)c1cc(C(=O)c2cccc(Cl)c2Cl)c[nH]1</smiles>

$35 a$<smiles>CCCC(=O)c1cc(C(=O)c2cccc(Cl)c2Cl)cn1C</smiles>
$\begin{aligned} \text { 37: } \mathrm{R} & =\mathrm{CH}_{3} \square \mathrm{b} \\ \text { 36e: } \mathrm{R} & =\mathrm{H}\end{aligned}$<smiles>Cn1cc(C(=O)c2cccc(Cl)c2Cl)cc1C(=O)NCc1cccnc1</smiles>

$6 \mathrm{~m}$

${ }^{a}$ Reagents and conditions: (a) NaH, DMF, MeI; (b) LiOH, THF, $\mathrm{H}_{2} \mathrm{O}, 60{ }^{\circ} \mathrm{C}$; (c) (i) CDI, THF, $70{ }^{\circ} \mathrm{C}$; (ii) 3-pyridylmethylamine, $50{ }^{\circ} \mathrm{C}-\mathrm{RT}$. 
Scheme $12^{a}$

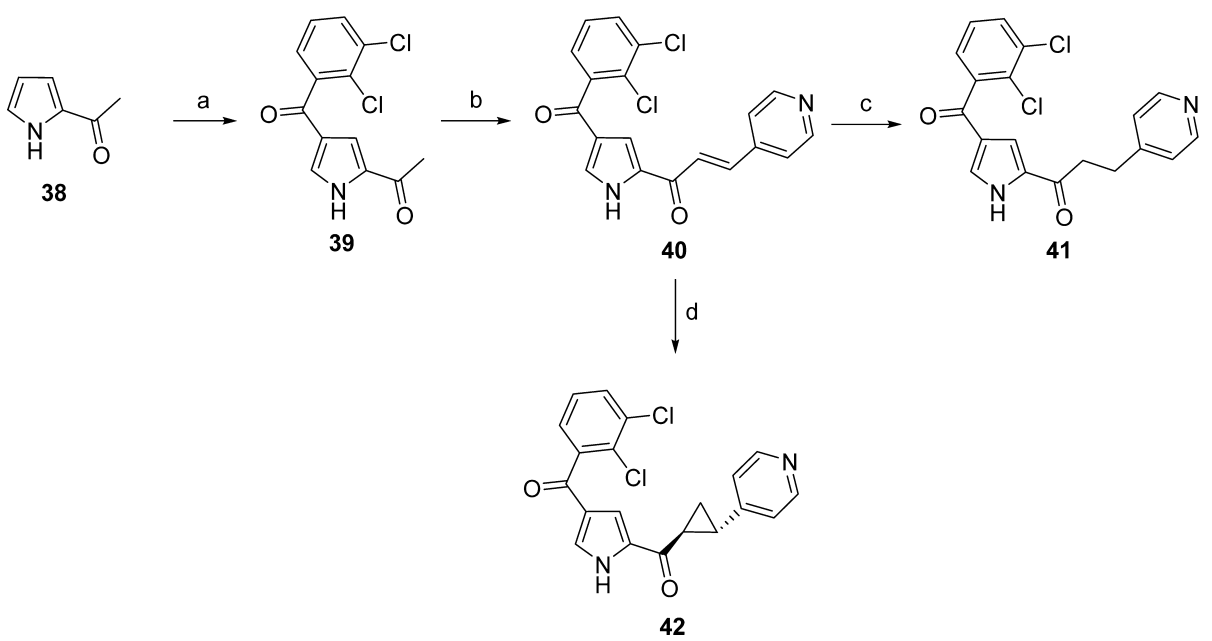

${ }^{a}$ Reagents and Conditions: (a) $\mathrm{AlCl}_{3}$, 2,3-dichlorobenzoyl chloride, DCM, $0{ }^{\circ} \mathrm{C}-\mathrm{RT}, 18 \mathrm{~h}$; (b) isonicotinaldehyde, $\mathrm{KOH}, \mathrm{EtOH}, \mathrm{H}_{2} \mathrm{O}, 0{ }^{\circ} \mathrm{C}-\mathrm{RT}, 18$ h; (c) indium powder, $\mathrm{NH}_{4} \mathrm{Cl}$, EtOH, $\mathrm{H}_{2} \mathrm{O}$, reflux, $8 \mathrm{~h}$; (d) $\left(\mathrm{CH}_{3}\right)_{2} \mathrm{SO}^{+} \mathrm{I}^{-}$, $\mathrm{KO}^{t} \mathrm{Bu}, \mathrm{DMSO}, \mathrm{RT}, 24 \mathrm{~h}$.

Scheme $13^{a}$<smiles>CCOC(=O)c1ccncc1</smiles>

${ }^{a}$ Reagents and conditions: (a) $\mathrm{KO}^{t} \mathrm{Bu}$, THF, RT, 6 h; (b) $\mathrm{AlCl}_{3}$, 2,3-dichlorobenzoyl chloride, DCM, $0{ }^{\circ} \mathrm{C}-\mathrm{RT}, 18 \mathrm{~h}$.

Cyanopyrimidine Series 5. A small series of 4-amino-2anilinopyrimidine-5-carbonitriles $(\mathbf{5 a}-\mathbf{c})$ were prepared by the reaction of the appropriate aniline with chloropyrimidine (33) at $100{ }^{\circ} \mathrm{C}$ in DMF (Scheme 9). ${ }^{24}$

4-Benzoylpyrrole-2-carboxamide Series 6. A selection of 4-benzoylpyrrole-2-carboxamides were prepared by FriedelCrafts acylation of methyl $1 H$-pyrrole-2-carboxylate (34) with a substituted benzoyl chloride giving pyrrole (35). Hydrolysis of the methyl ester with lithium hydroxide gave carboxylic acid 36 that was coupled with the appropriate amine using CDI to give the desired carboxamides $(\mathbf{6 a}-\mathbf{r})$ (Scheme 10). The $N$-methyl derivative $6 \mathrm{~m}$ was prepared by methylation of ester $35 \mathrm{a}$, followed by hydrolysis and coupling with 3-pyridylmethylamine (Scheme 11).

2-Substituted-4-benzoylpyrrole Derivatives. The alkene derivative $\mathbf{4 0}$ was prepared by aldol condensation of ketone 39 and isonicotinaldehyde (Scheme 12). Selective reduction was achieved by refluxing alkene $\mathbf{4 0}$ in aqueous ethanol with indium metal and ammonium chloride giving alkane 41 in moderate yield. $^{25}$ The cyclopropyl analogue $\mathbf{4 2}$ was prepared by a Corey Chaykovsky reaction. ${ }^{26}$ Thus, alkene $\mathbf{4 0}$ was reacted with trimethylsulfoxonium iodide and potassium tert-butoxide giving 42 in $12 \%$ yield. $^{27}$ Diketone $\mathbf{4 4}$ was prepared via a Claisen condensation between 1-(1H-pyrrol-2-yl)ethanone and methyl isonicotinate diketone 43 (Scheme 13). Friedel-Crafts acylation with 2,3-dichlorobenzoyl chloride gave 44 .

\section{DISCUSSION}

Selected examples of the HTS hits in the benzothiazole series (3a, 3b, 3i) were synthesized and reassayed. The ERK5

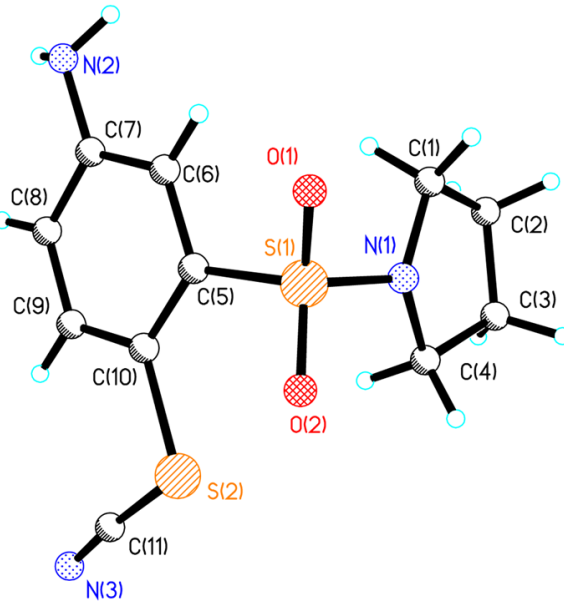

Figure 1. Crystal structure of 3-(pyrrolidin-1-ylsulfonyl)-4-thiocyanatobenzenamine 12a.

inhibitory activity for the resynthesized benzothiazoles were 1000-fold lower than for the library material (Table 2). Comparison of the ${ }^{1} \mathrm{H}$ NMR and LCMS spectra of the resynthesized and screened samples of $3 \mathbf{a}$ suggested that the library material was the 5-sulfonamide 9a, so authentic samples of isomers $9 \mathbf{a}$ and $\mathbf{9 b}$ were prepared. In order to eliminate the possibility of mis-identification of the compounds by spectroscopic methods, the identity of isothiocyanate 12a and benzothiazoles $3 \mathbf{a}$ and $3 \mathbf{i}$ were elucidated by small-molecule Xray crystallography (Figures 1-3). 


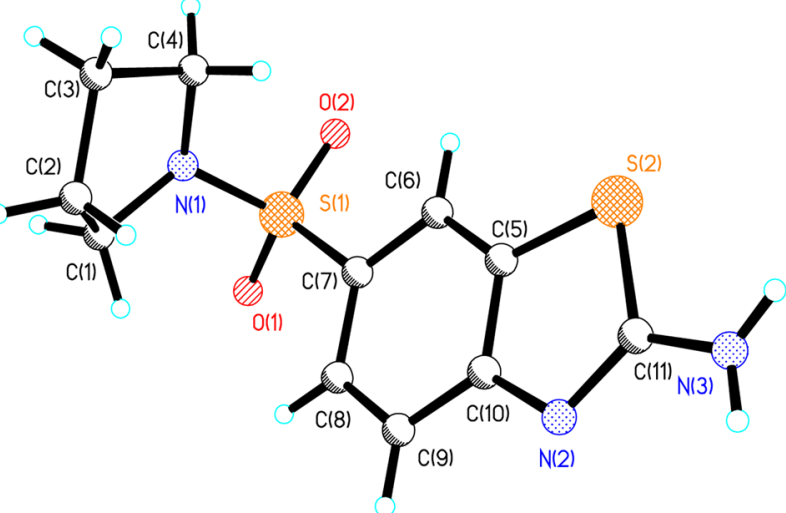

Figure 2. Crystal structure of 6-(pyrrolidine-1-sulfonyl)-benzothiazol-2ylamine 3a.

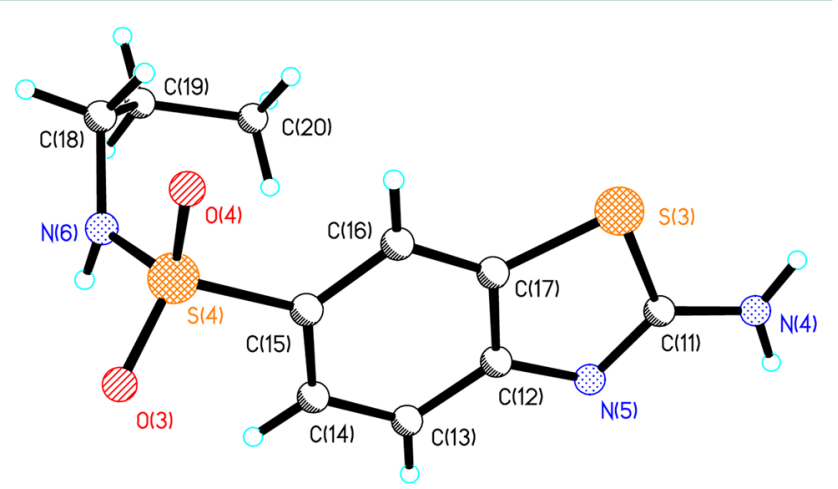

Figure 3. Crystal structure of 2-amino- $N$-propylbenzo[d]thiazole-6sulfonamide $3 \mathbf{i}$.

The assay results for these isomers also failed to replicate the initial $\mathrm{IC}_{50}$ values from the screening samples. Interestingly, the isothiocyanate side-product 12a showed 10 -fold greater potency than the benzothiazole, although this result was not replicated for the analogue $\mathbf{1 2 b}$. Time-dependent enzyme inactivation by isothiocyanates, via their reaction with lysine residues, has been reported. ${ }^{28}$ Further investigations into the mechanism of action of 12a were not conducted. Some aminothiazoles have recently been identified as frequent hitters from a fragment screening set and dubbed promiscuous 2-aminothiazoles (PrATs). ${ }^{29}$ The reason for the discrepancy between the activity of the HTS sample and the resynthesized material is not clear. Numerous mechanisms for false positives in HTS are possible, including the presence of trace impurities or protein aggregation, and further effort was not expended eliminating these possibilities. ${ }^{30}$

Three HTS hits in the nicotinonitrile series (4a, 19, and 31) were synthesized and reassayed (Tables 3 and 4 ). The results for the glycine derivative $4 \mathrm{a}$ and proline methyl ester derivative 19 were in good agreement with the HTS $\mathrm{IC}_{50}$ values. In contrast, the propan-2-one derivative $\mathbf{3 1}$ was 50 -fold less active than the HTS result. On this basis, a limited series of compounds was prepared to establish preliminary SARs and to determine the minimum inhibitory pharmacophore. The SARs for the 4- and 6substitutents were delineated keeping the 2-thio substituent as the glycine amide (Table 3). The 4,6-diphenyl, 4-phenyl-6methyl, and 4,6-dimethyl compounds (4d, 4j, and $4 \mathbf{k}$, respectively) were each devoid of activity. The 4-(2-fluorophenyl) derivative 4c was 7-fold less active than the 4-(4fluorophenyl) derivative $\mathbf{4 a}$, whereas the 4-(3-fluorophenyl) derivative $\mathbf{4 b}$ lacked measurable potency. The combination of 2 -
Table 4. ERK5 Inhibitory Activity of Nicotinonitrile Series 14a, 151, 17, 19-21, 23, 28, and 31-32

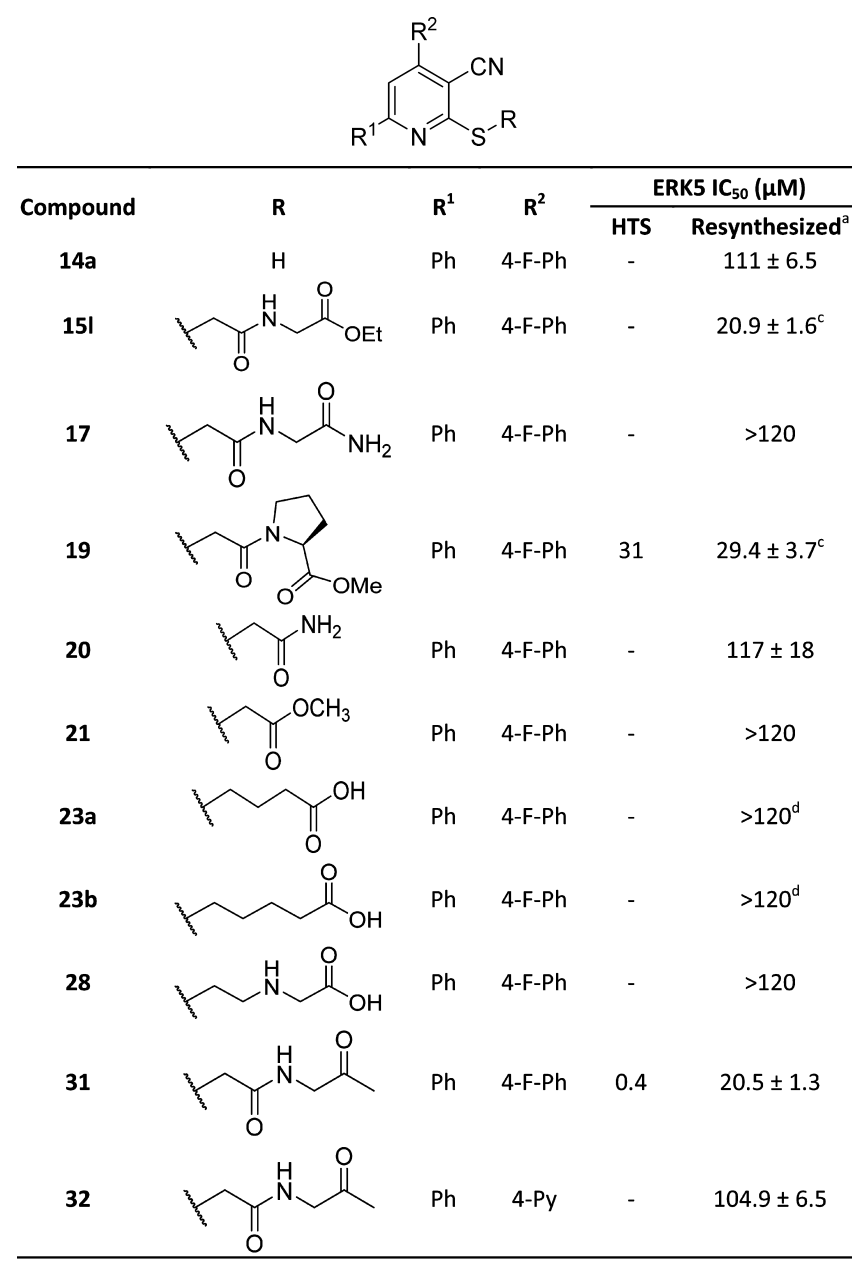

${ }^{a}$ Values are the mean of at least 3 determinations $\pm \mathrm{SD} .{ }^{b} n=1 .{ }^{c} n=2$. $d$ precipitation observed at $1.2 \mathrm{mM}$ in $40 \%$ DMSO.

Table 5. ERK5 Inhibitory Activity of Pyrimidine Series 5a-c<smiles>N#Cc1cnc(Nc2ccccc2)nc1N</smiles>

\begin{tabular}{|c|c|c|c|}
\hline \multirow[b]{2}{*}{ compound } & \multirow[b]{2}{*}{$\mathrm{R}$} & \multicolumn{2}{|c|}{ 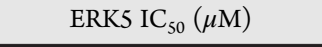 } \\
\hline & & HTS & resynthesized $^{a}$ \\
\hline $5 a$ & $2-\mathrm{CH}_{3}$ & 26 & $88 \pm 3$ \\
\hline $5 b$ & $3-\mathrm{OCH}_{3}$ & 11 & $23 \pm 7$ \\
\hline $5 c$ & 4-F & 6.5 & $12 \pm 3$ \\
\hline
\end{tabular}

${ }^{a}$ Values are the mean of at least 3 determinations \pm SD.

fluoro and 4-fluoro substituents (4f) was not additive and resulted in a 15-fold loss of potency compared with 4a. The 4-(4pyridyl) derivative $\mathbf{4 g}$ exhibited a 13 -fold loss in potency compared to $4 \mathrm{a}$, despite the similar electronic properties of the rings. Substitution of the 4-phenyl group with 4-trifluoromethyl $4 \mathrm{e}$, or 4-methoxy $4 \mathrm{~h}$ resulted in loss of activity.

The SARs for the thioether side-chain were investigated (Table 4). The pyridine thiol 14a lacking the amide side-chain showed a 20 -fold loss in potency compared to 4 a. The glycine ethyl ester 151 showed similar activity to the proline methyl ester derivative 19, and was 4-fold less potent than the corresponding glycine derivative 4a. In contrast, the glycine amide 17 lacked 
Table 6. ERK5 Inhibitory Activity of Pyrrole Carboxamides (6a-e)

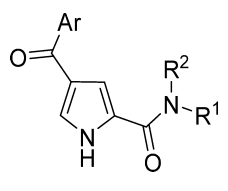

Compound

${ }^{a}$ Values are the mean of at least 3 determinations \pm SD. ${ }^{b} n=2$.

measurable activity. The shorter, unsubstituted amide $\mathbf{2 0}$ showed weak activity, whereas the corresponding ester $\mathbf{2 1}$ was inactive. Two thioalkyl carboxylic acids $\mathbf{2 3} \mathbf{a}$ and $\mathbf{2 3} \mathbf{b}$ were inactive, as was the corresponding amine $\mathbf{2 8}$, demonstrating the requirement for the amide group in the side chain for potency. Comparison of the 4-fluorophenyl propan-2-one derivative 31 with the 4-pyridyl derivative 32 showed a 5-fold loss in potency consistent with the results in the glycine amide series ( $4 a$ and $\mathbf{4 g}$ ).

Overall, each of the changes made to the hit compounds in the nicotinonitrile series (4a, 19, and 31$)$ resulted in loss of potency. Modifications to the aromatic and side-chain substituents revealed a highly constrained pharmacophore and limited SAR. As a result, no further optimization of this series was attempted. Interestingly, 3-cyano-4,6-diphenyl-pyridines have been identified recently as inhibitors of the PA-PB1 protein-protein interaction for influenza. ${ }^{31}$

The cyanopyrimidines $\mathbf{5 a}-\mathbf{c}$ showed reasonable activity against ERK5, with $\mathrm{IC}_{50}$ values in the $12-88 \mu \mathrm{M}$ range (Table 5 ), and generally consistent with the HTS values. The activity against ERK5 in this series was promising, but the series had also been selected for development against another target internally. For this reason, no further analogues were prepared. Kinase inhibitors incorporating a 5-cyanopyrimidine core have been reported, for example, Wee1 inhibitors ${ }^{32}$ and CDK2 inhibitors. ${ }^{33}$

Five 4-benzoylpyrrole-2-carboxamides $(6 a-e)$ gave good potency in the HTS. Upon resynthesis and retesting, the 2,3dichlorobenzoyl- $\mathrm{N}$-(4-fluorobenzyl) substitued analogue 6a maintained significant activity $\left(\mathrm{IC}_{50}=3.7 \mu \mathrm{M}\right)$ despite a 5-fold loss in potency compared to the HTS result (Table 6). Similarly, the 2-trifluoromethylbenzoyl- $N$-methyl substituted analogue $\mathbf{6 d}$ gave a 2 -fold drop in activity $\left(\mathrm{IC}_{50}=9.6 \mu \mathrm{M}\right)$ compared to the HTS result, and the benzoyl- $N$-methyl-3-pyridyl derivative 6 e gave a 3 -fold drop in activity $\left(\mathrm{IC}_{50}=26 \mu \mathrm{M}\right)$. In contrast, the resynthesized 2,4-dichlorobenzoyl analogues $\mathbf{6 b}$ and $\mathbf{6 c}$ bearing either the $\mathrm{N}, \mathrm{N}$-dimethylamide or $\mathrm{N}$-phenethylamide substituents, respectively, showed no activity.
Encouraged by these results, a small series of aroylpyrroles was prepared. Compounds were designed to establish the minimum kinase binding pharmacophore, and to explore possibilities to gain potency and selectivity by variation of the amide substituent. The benzoyl substituent was fixed as the most potent 2,3dichlorophenyl for all these examples.

Series $(\mathbf{6} \mathbf{f}-\mathbf{n})$ was prepared to explore simple variations to the amide moiety (Table 7). Monomethyl amide 6 f was equipotent with the parent 4-fluorobenzyl amide $6 \mathrm{a}$, whereas the dimethyl amide $6 \mathrm{~g}$ was 7 -fold less potent. Introduction of the 3pyridylmethyl amide from $\mathbf{6 e}$ or the 4-pyridylmethyl amide $\mathbf{6 h}$, retained potency, whereas the benzyl derivative $6 \mathbf{k}$ and 2-pyridyl derivative $\mathbf{6 j}$ were less potent, and phenylethyl amide $\mathbf{6} \mathbf{1}$ was inactive. Similar to $\mathbf{6 g}, \mathrm{N}$-methyl-(3-pyridylmethyl) amide derivative $6 \mathbf{n}$ was 7 -fold less potent than primary amide $6 \mathbf{i}$. Importantly, methylation of the pyrrole $\mathrm{NH}(6 \mathrm{~m})$ completely abolished ERK5 activity, indicating an essential interaction with the kinase at this position. In contrast, the relatively small drop in activity for the secondary amides $\mathbf{6} \mathbf{g}$ and $\mathbf{6}$ n suggested the amide $\mathrm{NH}$ was not forming a critical interaction, and that the drop in potency could be related to the conformational preference of the amide group. With this in mind, a limited number of conformationally restricted, 5- and 6-membered cyclic secondary amides were investigated (Table 8). The 3,4-dihydro-2,6naphthyridinyl and isoindolinyl derivatives (6o and $\mathbf{6 q}$ ) were inactive. In contrast, 3,4-dihydroisoquinolinyl $6 \mathrm{p}$ was 5-fold less potent than $\mathbf{6 h}$, a comparable to the loss in potency seen for the $\mathrm{N}$-methyl analogues, whereas the pyrrolidinopyridinyl $6 \mathrm{r}$ was equipotent with $\mathbf{6 h}$. Selected examples in this series were assayed in an orthogonal LANCE assay format (see Supporting Information), based on time-resolved fluorescence resonance energy transfer (FRET), to eliminate the possibility of false positives. In all cases, the LANCE results were comparable with those obtained using the IMAP assay.

To establish the minimum kinase binding pharmacophore, systematic isosteric replacements to the amide group were made. 
Table 7. ERK5 SAR for Pyrrole Carboxamides $(6 f-n)$<smiles>[R]N([R])C(=O)c1cc(C(=O)c2cccc(Cl)c2Cl)cn1[R]</smiles>

\begin{tabular}{|c|c|c|c|c|c|}
\hline \multirow{2}{*}{ Compound } & \multirow{2}{*}{$\mathrm{R}^{1}$} & \multirow{2}{*}{$R^{2}$} & \multirow{2}{*}{$R^{3}$} & \multicolumn{2}{|c|}{ ERK5 IC $_{50}(\mu \mathrm{M})$} \\
\hline & & & & IMAP $^{\mathrm{a}}$ & LANCE $^{a}$ \\
\hline $6 f$ & $\mathrm{H}$ & $\mathrm{H}$ & $\mathrm{CH}_{3}$ & $3.3 \pm 1.0^{b}$ & $3.6 \pm 1.0$ \\
\hline $6 \mathrm{~g}$ & $\mathrm{H}$ & $\mathrm{CH}_{3}$ & $\mathrm{CH}_{3}$ & $24 \pm 27^{c}$ & $44 \pm 24$ \\
\hline $6 \mathrm{~h}$ & $\mathrm{H}$ & $\mathrm{H}$ & & $2.0 \pm 2.0^{d}$ & - \\
\hline $6 \mathbf{i}$ & $\mathrm{H}$ & $\mathrm{H}$ & & $3.8 \pm 3.7^{c}$ & $1.1 \pm 0.4^{c}$ \\
\hline $6 \mathrm{j}$ & $\mathrm{H}$ & $\mathrm{H}$ & & $7.2 \pm 0.02$ & $3.9 \pm 0.8$ \\
\hline $6 k$ & $\mathrm{H}$ & $\mathrm{H}$ & & $21^{\mathrm{e}}$ & - \\
\hline 61 & $\mathrm{H}$ & $\mathrm{H}$ & & $>120$ & \\
\hline $6 \mathrm{~m}$ & $\mathrm{CH}_{3}$ & $\mathrm{H}$ & & $>120$ & - \\
\hline $6 n$ & $\mathrm{H}$ & $\mathrm{CH}_{3}$ & & $25 \pm 1.3$ & $13 \pm 1.9$ \\
\hline
\end{tabular}

${ }^{a}$ Determinations \pm standard deviation (mean of $n=2$ unless otherwise stated). ${ }^{b} \mathrm{IC}_{50}$ mean of $n=4 ;{ }^{c} \mathrm{IC}_{50}$ mean of $n=6 ;{ }^{d} \mathrm{IC}_{50}$ mean of $n=$ $10 ;{ }^{e} \mathrm{IC}_{50} n=1$.

The acetyl derivative 39 and the 1,3-diketone 44 were inactive (Table 9). In contrast, the unsaturated ketone $\mathbf{4 0}$ and the cyclopropyl ketone $\mathbf{4 2}$ retained similar activity to the parent $\mathbf{6 a}$, whereas the saturated ketone $\mathbf{4 1}$ was $\mathbf{1 0}$-fold less active. These results confirm that the amide $\mathrm{NH}$ is not required for activity, and that conformational rigidity at this position is favorable. The loss of activity for diketone $\mathbf{4 4}$ was explained by the preferred enol tautomer lacking an essential $\mathrm{H}$-bond to the kinase via the ketone adjacent to the pyrrole.

The most potent pyrrole inhibitor $\mathbf{6 h}$ was submitted for a kinase selectivity screen and gave a promising selectivity profile. Of the 20 kinases, screened only one kinase (SAPK2a or p38 $\alpha$ MAP kinase) was inhibited at $>50 \%$ inhibition $(10 \mu \mathrm{M})$. Subsequent to our identification of pyrrole-2-carboxamides as ERK5 inhibitors, similar compounds, e.g. 45, have been independently identified as p38 $\alpha$ MAP kinase inhibitors with micromolar activity. ${ }^{34}$ The X-ray structure of $\mathbf{4 5}$ shows it bound to the hinge of the kinase via hydrogen bonds from the pyrrole $\mathrm{NH}$ and the carboxamide carbonyl, with the aryl portion occupying the lipophilic region close to the gatekeeper, and the furan binding in the outer lipophilic region. ERK5 shares $48 \%$ sequence homology with p $38 \alpha$ MAP kinase, and 58\% homology in the kinase domain. In addition, the gatekeeper residues of the kinases are similar, with leucine in ERK5 and threonine in p38 $\alpha$ MAP kinase. The ERK5 SAR for our series is consistent with a similar binding mode to ERK5 as seen in the p38 X-ray structure, in particular the donor/acceptor doublet of H-bonds from the pyrrole $\mathrm{NH}$ and amide carbonyl to the kinase.

At this point, given the similarity between the published p $38 \alpha$ MAP kinase inhibitors and our hit series, we needed to establish selectivity vs p38 $\alpha$ MAP kinase to provide useful ERK5 tool compounds or therapeutic agents. ${ }^{34,35}$ Thus, selected compounds were counterscreened against $\mathrm{p} 38 \alpha$ MAP kinase using a LANCE assay. As anticipated, the 2-pyridyl derivatives $6 \mathbf{j}$ and 3,4-dihydroisoquinolinyl derivative $6 \mathrm{p}$ were equipotent for both p38 $\alpha$ MAP kinase and ERK5. Importantly, the pyrrolidinopyridinyl derivative $6 \mathrm{r}$ was inactive in the $\mathrm{p} 38 \alpha$ assay. The ability to eliminate p38 $\alpha$ MAP kinase activity while maintaining ERK5 activity by variation of the amide side chain was not readily predicted from the published $\mathrm{p} 38 \alpha \mathrm{X}$-ray structure and points to differing structural requirements around the amide side-chain that may be exploited in further development of the series.

\section{CONCLUSIONS}

The IMAP FP high-throughput screen for ERK5 returned four distinct chemical series as hits. Synthesis of the hits and selected close analogues demonstrated that the HTS activity of the benzothiazoles 3 was not reproducable, activity for the cyanopyridine hits $(4 \mathbf{a}, 19)$ was reproducable, but the limited scope to develop the SAR ruled this series out, and two series with confirmed active hits. The lack of activity of these hits was disappointing but not atypical in screening campaigns. The cyanopyrimidine hits $\mathbf{5 a - c}$ were not pursued for reasons of competition. The remaining series, the pyrrole carboxamides 6a-e, demonstrated consistent ERK5 activity, with SARs consistent with a kinase hinge binder. Selectivity against the close homologue p38 $\alpha$ MAP kinase was achieved without loss of ERK5 activity through minor structural modification, and a representative example $\mathbf{6 h}$ showed an acceptable kinase selectivity profile in a panel. At this stage the pyrrole carboxamides demonstrated tractable synthesis, intelligible preliminary SARs, and promising selectivity. The relatively modest kinase inhibitory activity achieved at this stage did not give any concern as the pharmacophore established presented opportunities to optimize potency at both the benzoyl and amide portions, indepenently. Having demonstrated the necessary requirements to progress to the hit-to-lead optimization stage, further SAR studies were undertaken, with an initial focus on improving potency, which will be reported separately. ${ }^{36}$

\section{EXPERIMENTAL PROCEDURES}

IMAP Substrate Mapping. Nonphosphorylated and phosphorylated versions of each ERK5 sequence (Table 1) were obtained from the CRUK Peptide Synthesis Research Services group. The substrate finder kit was used according to the manufacturer's instructions. Reaction buffer $(10 \mu \mathrm{L})$ containing ATP $(100 \mu \mathrm{M})$ was added to wells of the plate to reconstitute 5FAM labeled substrates. Reaction buffer $(10 \mu \mathrm{L})$ with or without ERK5 $(6.4 \mathrm{ng} / \mu \mathrm{L})$ was added to appropriate wells of the plate, to generate background controls and positive controls. The reaction was incubated for $1 \mathrm{~h}$ at ambient temperature after which IMAP Binding Solution $(60 \mu \mathrm{L})$ was added. After a further $1 \mathrm{~h}$ of incubation the fluorescence polarization was measured. The results were analyzed using the IMAP Substrate Mapper provided with the kit.

Kinetic Characterization of ERK5. Reactions were carried out with varying concentrations of ATP at constant substrate and 
Table 8. SAR for Cyclic Pyrrole Carboxamides (6j, 6o-r) against ERK5 and p38 $\alpha$<smiles>[R]C(=O)c1cc(C(=O)c2cccc(Cl)c2Cl)c[nH]1</smiles>

\begin{tabular}{|c|c|c|c|c|}
\hline \multirow{2}{*}{ Compound ID } & \multirow{2}{*}{$\mathbf{R}$} & \multicolumn{2}{|c|}{ ERK5 IC50 $(\mu \mathrm{M})^{\mathrm{a}}$} & \multirow{2}{*}{$\begin{array}{c}\text { p38 } \alpha \text { LANCE } \\
\mathrm{IC}_{50}(\mu \mathrm{M})^{\mathrm{a}}\end{array}$} \\
\hline & & IMAP & LANCE & \\
\hline $6 \mathbf{j}$ & & $7.2 \pm 0.03$ & & $4.3 \pm 1.2^{b}$ \\
\hline 60 & & $>120$ & - & \\
\hline $6 p$ & & $11 \pm 2.3^{b}$ & $25 \pm 1.8$ & $28 \pm 20$ \\
\hline $6 q$ & & $>120$ & - & \\
\hline $6 r$ & & $2.7 \pm 0.4$ & - & $>120$ \\
\hline
\end{tabular}

${ }^{a}$ Determinations \pm standard deviation (mean of $n=2$ unless otherwise stated). ${ }^{b} \mathrm{IC}_{50}$ mean of $n=4$.

Table 9. ERK5 SAR for Pyrroles $(39-42,44)$<smiles>[R]C(=O)c1cc(C(=O)c2cccc(Cl)c2Cl)c[nH]1</smiles>

\begin{tabular}{|c|c|c|c|}
\hline \multirow{2}{*}{ Compound ID } & \multirow{2}{*}{$\mathbf{R}$} & \multicolumn{2}{|c|}{ ERK5 IC $\mathrm{C}_{50}(\mu \mathrm{M})^{\mathrm{a}}$} \\
\hline & & IMAP & LANCE \\
\hline 39 & $\mathrm{CH}_{3}$ & $>120$ & - \\
\hline 40 & & $3.1 \pm 0.1^{b}$ & - \\
\hline 41 & & $23 \pm 4.4$ & $24 \pm 2.2$ \\
\hline 42 & & $6.8 \pm 2.0$ & $16 \pm 5.7^{c}$ \\
\hline 44 & & $>120$ & - \\
\hline
\end{tabular}

${ }^{a}$ Determinations \pm standard deviation (mean of $n=2$ unless otherwise stated). ${ }^{b}$ Mean of $n=4$. ${ }^{c}$ Mean of $n=6$.

enzyme concentrations. Because of limitations of the IMAP FP assay with respect to ATP concentrations, we utilized a transfer method to increase the maximum concentration of ATP that can be used. Reactions were conducted as normal in $10 \mu \mathrm{L}$ reaction volume. After either $1,2,3$, or $4 \mathrm{~h}$ incubation period at $37^{\circ} \mathrm{C}, 4$ $\mu \mathrm{L}$ of the reaction was transferred to $196 \mu \mathrm{L}$ of reaction buffer followed by a subsequent transfer of $10 \mu \mathrm{L}$ of this solution to 30 $\mu \mathrm{L}$ of IMAP Binding Solution. Rates of reaction at $1 \mathrm{~h}$ reaction time at the range of substrate concentrations were determined, and kinetic parameters were determined by nonlinear regression fitting of the data to the Michaelis-Menten eq (eq 1); curve fitting was performed using GraphPad Prism software. ${ }^{37}$

ERK5 High-Throughput Screen. Compounds were assayed in a $10 \mu \mathrm{L}$ reaction mixture per well containing: 1 in 700 dilution of ERK5 stock from CRT, $100 \mathrm{nM}$ peptide R7129 and $100 \mu \mathrm{M}$ of ATP. The reactions were performed with $10 \mathrm{mM}$ Tris- $\mathrm{HCl}(\mathrm{pH}$ 7.2), $10 \mathrm{mM} \mathrm{MgCl}_{2}, 0.05 \% \mathrm{NaN}_{3}$, and $0.01 \%$ Tween-20. Reactions were incubated for $3 \mathrm{~h}$ at $37^{\circ} \mathrm{C}$, followed by addition of $30 \mu \mathrm{L}$ of IMAP binding solution ( 1 in 600 dilution of IMAP binding reagent in $60 \%$ Binding Buffer A and $40 \%$ Binding Buffer B) and a further incubation for $2 \mathrm{~h}$ at ambient temperature. Plates were read on an Analyst HT microplate reader and the data analyzed using ActivityBase.

ERK5 IC $_{50}$ Determination (IMAP). The enzyme reaction was run as described for the HTS but using $300 \mu \mathrm{M}$ ATP, 250 $\mathrm{nM}$ peptide and a reduced incubation time of $2 \mathrm{~h}$ at $37^{\circ} \mathrm{C}$. One $\mu \mathrm{L}$ of this reaction was then transferred to a new assay plate and 9 $\mu \mathrm{L}$ of reaction buffer was added followed by $30 \mu \mathrm{L}$ of IMAP binding solution.

X-ray Crystallography. Data were collected on an Oxford Diffraction Gemini A Ultra diffractometer for 3i, using MoK $\alpha$ radiation $(\lambda=0.71073 \AA)$ at $150 \mathrm{~K}$, and on a Bruker Apex 2 diffractometer for $3 \mathbf{a}$ and $12 \mathrm{a}$, using synchrotron radiation $(\lambda=$ 0.6946 Å; SRS station 9.8, Daresbury Laboratory) at $120 \mathrm{~K}$ 
because of the very small size of crystals available. Corrections were made for synchrotron beam decay and for absorption and other systematic effects on the basis of repeated and equivalent data. The structures were solved by direct methods and refined on all unique $F^{2}$ values with anisotropic non-hydrogen atoms, with freely refined isotropic $\mathrm{H}$ atoms bonded to $\mathrm{N}$, and with a riding model for $\mathrm{H}$ atoms bonded to $\mathrm{C}$. All four structures are fully ordered; $3 \mathbf{i}$ have two independent molecules in the asymmetric unit, and the noncentrosymmetric but achiral crystal structure of $3 \mathbf{i}$ displays inversion twinning with essentially equal components. Full crystallographic details are given in the Supporting Information. Programs were standard Oxford Diffraction CrysAlisPro ${ }^{38}$ and Bruker Apex $2^{39}$ for data collection and processing, and SHELXTL ${ }^{40}$ and SHELXL-2014_ENREF_52_ENREF_53 ${ }^{41}$ for structure solution and refinement. $\overline{\mathrm{CCD}} \overline{\mathrm{C}}$ references: 1410001,141003 , and 1410004 .

\section{ASSOCIATED CONTENT}

\section{S Supporting Information}

The Supporting Information is available free of charge on the ACS Publications website at DOI: 10.1021/acscombsci.5b00155.

Additional screening and synthesis information, X-ray crystal structure data for compounds $12 \mathrm{a}, 3 \mathbf{a}$, and $3 \mathbf{i}$, synthetic procedures, ERK5 and p38 $\alpha$ LANCE assay protocols, kinase selectivity data for $\mathbf{6 h}$. (PDF)

Crystallographic information file for compounds 12a, 3a, and $3 \mathbf{i}(\mathrm{CIF})$

\section{AUTHOR INFORMATION}

\section{Corresponding Author}

*E-mail: Ian.Hardcastle@ncl.ac.uk.

\section{Funding}

This work was supported by Cancer Research UK (C240/ A7409, C1296/A6963 and C2115/A21421), EPSRC equipment grant $(\mathrm{EP} / \mathrm{F} 03637 \mathrm{X} / 1)$, and the synchrotron component of the UK National Crystallography Service 2001-2010 (EP/ D07746X/1).

\section{Notes}

The authors declare no competing financial interest.

\section{ACKNOWLEDGMENTS}

We thank CCLRC for access to synchrotron diffraction facilities at SRS. The use of the EPSRC National Mass Spectroscopy Facility, Swansea University is gratefully acknowledged.

\section{REFERENCES}

(1) (a) Zhou, G.; Bao, Z. Q.; Dixon, J. E. Components of a New Human Protein Kinase Signal Transduction Pathway. J. Biol. Chem. 1995, 270 (21), 12665-12669. (b) Zhou, G. C.; Bao, A.; Guan, K. L.; Dixon, J. E. Specifical Interactions Between Newly Identified Human Kinases, Mek5 And Erk5. FASEB J. 1995, 9 (6), A1306-A1306. (c) Abe, J.; Kusuhara, M.; Ulevitch, R. J.; Berk, B. C.; Lee, J. D. Big mitogenactivated protein kinase 1 (BMK1) is a redox-sensitive kinase. J. Biol. Chem. 1996, 271 (28), 16586-16590.

(2) Hayashi, M.; Lee, J. D. Role of the BMK1/ERK5 signaling pathway: lessons from knockout mice. J. Mol. Med. 2004, 82 (12), 800-8.

(3) English, J. M.; Pearson, G.; Hockenberry, T.; Shivakumar, L.; White, M. A.; Cobb, M. H. Contribution of the ERK5/MEK5 pathway to Ras/Raf signaling and growth control. J. Biol. Chem. 1999, 274 (44), 31588-92.

(4) Wang, X.; Tournier, C. Regulation of cellular functions by the ERK5 signalling pathway. Cell. Signalling 2006, 18 (6), 753-60.
(5) Roberts, O. L.; Holmes, K.; Muller, J.; Cross, D. A.; Cross, M. J. ERK5 and the regulation of endothelial cell function. Biochem. Soc. Trans. 2009, 37 (Pt 6), 1254-9.

(6) (a) Kato, Y.; Kravchenko, V. V.; Tapping, R. I.; Han, J.; Ulevitch, R. J.; Lee, J.-D. BMK1/ERK5 regulates serum-induced early gene expression through transcription factor MEF2C. EMBO J. 1997, 16 (23), 7054-7066. (b) Yang, C. C.; Ornatsky, O. I.; McDermott, J. C.; Cruz, T. F.; Prody, C. A. Interaction of myocyte enhancer factor 2 (MEF2) with a mitogen-activated protein kinase, ERK5/BMK1. Nucleic Acids Res. 1998, 26 (20), 4771-4777. (c) Kato, Y.; Tapping, R. I.; Huang, S.; Watson, M. H.; Ulevitch, R. J.; Lee, J.-D. Bmk1/Erk5 is required for cell proliferation induced by epidermal growth factor. Nature 1998, 395 (6703), 713-716. (d) English, J. M.; Pearson, G.; Baer, R.; Cobb, M. H. Identification of Substrates and Regulators of the Mitogen-activated Protein Kinase ERK5 Using Chimeric Protein Kinases. J. Biol. Chem. 1998, 273 (7), 3854-3860. (e) Kamakura, S.; Moriguchi, T.; Nishida, E. Activation of the Protein Kinase ERK5/ BMK1 by Receptor Tyrosine Kinases. J. Biol. Chem. 1999, 274 (37), 26563-26571. (f) Pearson, G.; English, J. M.; White, M. A.; Cobb, M. H. ERK5 and ERK2 Cooperate to Regulate NF- $\kappa$ B and Cell Transformation. J. Biol. Chem. 2001, 276 (11), 7927-7931. (g) Terasawa, K.; Okazaki, K.; Nishida, E. Regulation of c-Fos and Fra-1 by the MEK5ERK5 pathway. Genes Cells 2003, 8 (3), 263-273.

(7) (a) Hayashi, M.; Fearns, C.; Eliceiri, B.; Yang, Y.; Lee, J. D. Big mitogen-activated protein kinase 1/extracellular signal-regulated kinase 5 signaling pathway is essential for tumor-associated angiogenesis. Cancer Res. 2005, 65 (17), 7699-7706. (b) Le, N.-T; Heo, K.-S.; Takei, Y.; Lee, H.; Woo, C.-H.; Chang, E.; McClain, C.; Hurley, C.; Wang, X.; Li, F.; Xu, H.; Morrell, C.; Sullivan, M. A.; Cohen, M. S.; Serafimova, I. M.; Taunton, J.; Fujiwara, K.; Abe, J.-I. A Crucial Role for p90RSKMediated Reduction of ERK5 Transcriptional Activity in Endothelial Dysfunction and Atherosclerosis. Circulation 2013, 127 (4), 486. (c) Ranganathan, A.; Pearson, G. W.; Chrestensen, C. A.; Sturgill, T. W.; Cobb, M. H. The MAP kinase ERK5 binds to and phosphorylates p90 RSK. Arch. Biochem. Biophys. 2006, 449 (1-2), 8-16.

(8) (a) Drew, B. A.; Burow, M. E.; Beckman, B. S. MEK5/ERK5 pathway: the first fifteen years. Biochim. Biophys. Acta, Rev. Cancer 2012, 1825 (1), 37-48. (b) Lochhead, P. A.; Gilley, R.; Cook, S. J. ERK5 and its role in tumour development. Biochem. Soc. Trans. 2012, 40 (1), 2516.

(9) (a) Mehta, P. B.; Jenkins, B. L.; McCarthy, L.; Thilak, L.; Robson, C. N.; Neal, D. E.; Leung, H. Y. MEK5 overexpression is associated with metastatic prostate cancer, and stimulates proliferation, MMP-9 expression and invasion. Oncogene 2003, 22 (9), 1381-1389. (b) McCracken, S. R.; Ramsay, A.; Heer, R.; Mathers, M. E.; Jenkins, B. L.; Edwards, J.; Robson, C. N.; Marquez, R.; Cohen, P.; Leung, H. Y. Aberrant expression of extracellular signal-regulated kinase 5 in human prostate cancer. Oncogene 2008, 27 (21), 2978-88.

(10) Montero, J. C.; Ocana, A.; Abad, M.; Ortiz-Ruiz, M. J; Pandiella, A.; Esparis-Ogando, A. Expression of ERK5 in Early Stage Breast Cancer and Association with Disease Free Survival Identifies this Kinase as a Potential Therapeutic Target. PLoS One 2009, 4 (5), e5565.

(11) Zen, K.; Yasui, K.; Nakajima, T.; Zen, Y.; Zen, K.; Gen, Y.; Mitsuyoshi, H.; Minami, M.; Mitsufuji, S.; Tanaka, S.; Itoh, Y.; Nakanuma, Y.; Taniwaki, M.; Arii, S.; Okanoue, T.; Yoshikawa, T. ERK5 is a target for gene amplification at $17 \mathrm{p} 11$ and promotes cell growth in hepatocellular carcinoma by regulating mitotic entry. Genes, Chromosomes Cancer 2009, 48 (2), 109-120.

(12) Arias-González, L.; Moreno-Gimeno, I.; del Campo, A. R.; Serrano-Oviedo, L.; Valero, M. L.; Esparís-Ogando, A.; de la CruzMorcillo, M. Á.; Melgar-Rojas, P.; García-Cano, J.; Cimas, F. J.; Hidalgo, M. J. R.; Prado, A.; Callejas-Valera, J. L.; Nam-Cha, S. H.; GiménezBachs, J. M.; Salinas-Sánchez, A. S.; Pandiella, A.; del Peso, L.; SánchezPrieto, R. ERK5/BMK1 Is a Novel Target of the Tumor Suppressor VHL: Implication in Clear Cell Renal Carcinoma. Neoplasia 2013, 15 (6), 649-659.

(13) Tatake, R. J.; O’Neill, M. M.; Kennedy, C. A.; Wayne, A. L.; Jakes, S.; Wu, D.; Kugler, S. Z., Jr; Kashem, M. A.; Kaplita, P.; Snow, R. J. 
Identification of pharmacological inhibitors of the MEK5/ERK5 pathway. Biochem. Biophys. Res. Commun. 2008, 377 (1), 120-125.

(14) Yang, Q.; Deng, X.; Lu, B.; Cameron, M.; Fearns, C.; Patricelli, M. P.; Yates, J. R.; Gray, N. S.; Lee, J.-D. Pharmacological Inhibition of BMK1 Suppresses Tumor Growth through Promyelocytic Leukemia Protein. Cancer Cell 2010, 18 (4), 396.

(15) Elkins, J. M.; Wang, J.; Deng, X.; Pattison, M. J.; Arthur, J. S. C.; Erazo, T.; Gomez, N.; Lizcano, J. M.; Gray, N. S.; Knapp, S. X-ray Crystal Structure of ERK5 (MAPK7) in Complex with a Specific Inhibitor. J. Med. Chem. 2013, 56 (11), 4413-4421.

(16) Sureban, S. M.; May, R.; Weygant, N.; Qu, D.; Chandrakesan, P.; Bannerman-Menson, E.; Ali, N.; Pantazis, P.; Westphalen, C. B.; Wang, T. C.; Houchen, C. W. XMD8-92 inhibits pancreatic tumor xenograft growth via a DCLK1-dependent mechanism. Cancer Lett. 2014, 351 (1), $151-161$.

(17) Rovida, E.; Di Maira, G.; Tusa, I.; Cannito, S.; Paternostro, C.; Navari, N.; Vivoli, E.; Deng, X.; Gray, N. S.; Esparís-Ogando, A.; David, E.; Pandiella, A.; Dello Sbarba, P.; Parola, M.; Marra, F. The mitogenactivated protein kinase ERK5 regulates the development and growth of hepatocellular carcinoma. Gut 2015, 64 (9), 1454-1465.

(18) Finegan, K. G.; Perez-Madrigal, D.; Hitchin, J. R.; Davies, C. C.; Jordan, A. M.; Tournier, C. ERK5 Is a Critical Mediator of Inflammation-Driven Cancer. Cancer Res. 2015, 75 (4), 742-753.

(19) (a) Collins, I.; Workman, P. New approaches to molecular cancer therapeutics. Nat. Chem. Biol. 2006, 2 (12), 689-700. (b) Hughes, J. P.; Rees, S.; Kalindjian, S. B.; Philpott, K. L. Principles of early drug discovery. Br. J. Pharmacol. 2011, 162 (6), 1239-1249.

(20) (a) Barton, D.; Ollis, W. D. Heterocyclic Compounds; Pergamon: Oxford, NY, 1979; Vol. 4. (b) Jordan, A. D.; Luo, C.; Reitz, A. B. Efficient Conversion of Substituted Aryl Thioureas to 2-Aminobenzothiazoles Using Benzyltrimethylammonium Tribromide. J. Org. Chem. 2003, 68 (22), 8693-8696. (c) Ding, Q; He, X.; Wu, J. Synthesis of 2Aminobenzothiazole via Copper(I)-Catalyzed Tandem Reaction of 2Iodobenzenamine with Isothiocyanate. J. Comb. Chem. 2009, 11 (4), 587-591. (d) Li, Z.; Xiao, S.; Tian, G.; Zhu, A.; Feng, X.; Liu, J. Microwave Promoted Environmentally Benign Synthesis of 2-Aminobenzothiazoles and Their Urea Derivatives. Phosphorus, Sulfur Silicon Relat. Elem. 2008, 183 (5), 1124-1133. (e) Jordan, A. D.; Luo, C.; Reitz, A. B. Efficient Conversion of Substituted Aryl Thioureas to 2Aminobenzothiazoles Using Benzyltrimethylammonium Tribromide. J. Org. Chem. 2003, 68 (22), 8693-8696.

(21) Nagarajan, S. R.; De Crescenzo, G. A.; Getman, D. P.; Lu, H.-F.; Sikorski, J. A.; Walker, J. L.; McDonald, J. J.; Houseman, K. A.; Kocan, G. P.; Kishore, N.; Mehta, P. P.; Funkes-Shippy, C. L.; Blystone, L. Discovery of novel benzothiazolesulfonamides as potent inhibitors of HIV-1 protease. Bioorg. Med. Chem. 2003, 11 (22), 4769-4777.

(22) Shestopalov, A. M.; Nikishin, K. G. One stage synthesis of 4,6diaryl-3-cyanopyridine-2(1H)-thiones. Chem. Heterocycl. Compd. 1998, 34, 1093.

(23) Hepworth, J. D. Aminoacetone Semicarbazone Hydrochloride. Organic Syntheses, Coll. Vol. 1973, 5, 27.

(24) Schmidt, H.-W.; Koitz, G.; Junek, H. A convenient synthesis of 2substituted 4-amino-5-pyrimidinecarbonitriles. J. Heterocycl. Chem. 1987, 24 (5), 1305-1307.

(25) Ranu, B. C.; Dutta, J.; Guchhait, S. K. Indium metal as a reducing agent. Selective reduction of the carbon-carbon double bond in highly activated conjugated alkenes. Org. Lett. 2001, 3 (16), 2603-2605.

(26) Corey, E. J.; Chaykovsky, M. Dimethyloxosulfonium methylide $\left(\left(\mathrm{CH}_{3}\right)_{2} \mathrm{SOCH}_{2}\right)$ and dimethylsulfonium methylide $\left(\left(\mathrm{CH}_{3}\right)_{2} \mathrm{SCH}_{2}\right)$. Formation and application to organic synthesis. J. Am. Chem. Soc. 1965, 87 (6), 1353-1364.

(27) Ciaccio, J. A.; Aman, C. E. Instant Methylide" Modification of the Corey-Chaykovsky Cyclopropanation Reaction. Synth. Commun. 2006, 36 (10), 1333-1341.

(28) Wu, Q.; Caine, J. M.; Thomson, S. A.; Slavica, M.; Grunewald, G. L.; McLeish, M. J. Time-dependent inactivation of human phenylethanolamine $\mathrm{N}$-methyltransferase by 7-isothiocyanatotetrahydroisoquinoline. Bioorg. Med. Chem. Lett. 2009, 19 (4), 1071-1074.
(29) Devine, S. M.; Mulcair, M. D.; Debono, C. O.; Leung, E. W. W.; Nissink, J. W. M.; Lim, S. S.; Chandrashekaran, I. R.; Vazirani, M.; Mohanty, B.; Simpson, J. S.; Baell, J. B.; Scammells, P. J.; Norton, R. S.; Scanlon, M. J. Promiscuous 2-Aminothiazoles (PrATs): A Frequent Hitting Scaffold. J. Med. Chem. 2015, 58 (3), 1205-1214.

(30) Baell, J. B.; Holloway, G. A. New Substructure Filters for Removal of Pan Assay Interference Compounds (PAINS) from Screening Libraries and for Their Exclusion in Bioassays. J. Med. Chem. 2010, 53 (7), 2719-2740.

(31) Trist, I. M. L.; Nannetti, G.; Tintori, C.; Fallacara, A. L.; Deodato, D.; Mercorelli, B.; Palù, G.; Wijtmans, M.; Gospodova, T.; Edink, E.; Verheij, M.; de Esch, I.; Viteva, L.; Loregian, A.; Botta, M. 4,6Diphenylpyridines as Promising Novel Anti-Influenza Agents Targeting the PA-PB1 Protein-Protein Interaction: Structure-Activity Relationships Exploration with the Aid of Molecular Modeling. J. Med. Chem. 2016, 59 (6), 2688-2703.

(32) Thomas, A. P. Preparation and formulation of 4-amino-5-cyano2-anilino-pyrimidines as inhibitors of cell-cycle kinases for pharmaceutical use in the treatment of cancer Int. Patent WO 1998033798 A2, 2001

(33) Marchetti, F.; Cano, C.; Curtin, N. J.; Golding, B. T.; Griffin, R. J.; Haggerty, K.; Newell, D. R.; Parsons, R. J.; Payne, S. L.; Wang, L. Z.; Hardcastle, I. R. Synthesis and biological evaluation of 5-substituted O4alkylpyrimidines as CDK2 inhibitors. Org. Biomol. Chem. 2010, 8 (10), 2397-2407.

(34) Down, K.; Bamborough, P.; Alder, C.; Campbell, A.; Christopher, J. A.; Gerelle, M.; Ludbrook, S.; Mallett, D.; Mellor, G.; Miller, D. D.; Pearson, R.; Ray, K.; Solanke, Y.; Somers, D. The discovery and initial optimization of pyrrole-2-carboxamides as inhibitors of p38[alpha] MAP kinase. Bioorg. Med. Chem. Lett. 2010, 20 (13), 3936-3940.

(35) Workman, P.; Collins, I. Probing the Probes: Fitness Factors For Small Molecule Tools. Chem. Biol. 2010, 17 (6), 561-577.

(36) Reuillon, T.; Miller, D.; Myers, S.; Molyneux, L.; Cano, C.; Hardcastle, I. R.; Griffin, R. J.; Rigoreau, L.; Golding, B. T.; Noble, M. E. N. Pyrrolcarboxamide Derivatives For The Inhibition of ERK5. Int Patent WO/2016/042341.

(37) Prism, version 6; GraphPad Software Inc., 2014.

(38) CrysAlisPro; Oxford Diffraction: Oxford, UK, 2008.

(39) Apex2; Bruker AXS Inc.: Madison, MI, USA, 2008.

(40) Sheldrick, G. A short history of SHELX. Acta Crystallogr., Sect. A: Found. Crystallogr. 2008, 64 (1), 112-122.

(41) Sheldrick, G. Crystal structure refinement with SHELXL. Acta Crystallogr., Sect. C: Struct. Chem. 2015, 71 (1), 3-8. 